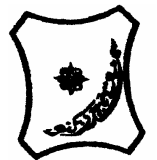

Bayero Journal of Pure and Applied Sciences, 7(1): 85 - 89

Received: May 2014

Accepted: June 2014

ISSN $2006-6996$

\title{
MINERAL ELEMENTS CONTENT OF SOME COARSE GRAINS USED AS STAPLE FOOD IN KANO METROPOLIS, NIGERIA
}

Mohammed, M.I. and Ahmad, U. M.

Department of Pure and Industrial Chemistry, Bayero University, P.M.B 3011, Kano. *Correspondence author: umarfarouqyola@yahoo.com

\begin{abstract}
Analysis of mineral elements were carried out on some coarse grains used as staple food in Kano metropolis. The levels of Magnesium, Calcium, Manganese, Iron, Copper and Zinc were determined using atomic absorption spectrophotometer (AAS), and that of Sodium and Potassium were obtained using flame photometer (FES). The result of the study shows that the mean results of the mineral elements ranged in $\mathrm{mg} / \mathrm{kg}$ from $62.50 \pm 0.55-84.82 \pm 0.74$ sodium, $73.33 \pm 0.35-317 \pm 0.10$ magnesium, 89.22 \pm 0.26 - 193.33 \pm 0.19 potassium, $70.00 \pm 0.52-186.67 \pm 0.29 \mathrm{calcium}, 1.00 \pm 0.11$

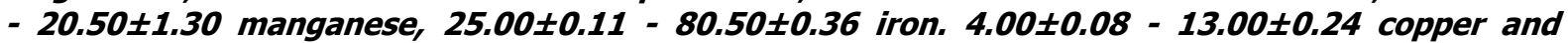
$15.00 \pm 0.34-50.50 \pm 0.24$ zinc. There was significant difference $(p<0.05)$ in levels of sodium, potassium and calcium between the varieties of coarse grains whereas no significant differences ( $p>0.05$ ) occur in levels of magnesium, manganese, copper and zinc between the varieties of coarse grains. In comparison with Recommended Dietary Allowances of essential and trace metals set by international standard organizations, the coarse grains analyzed in this work contribute little to the provision of essential and trace elements requirements.

Keywords: Mineral Elements, Coarse Grains, Staple Food, Kano, Nigeria.
\end{abstract}

\section{INTRODUCTION}

Food security is of growing global concern, including the reliability of supply and the quality of food. Food composition data is necessary when estimating a population's intake of nutrients and dietary exposure to toxins and indeed, assessing diet quality (Johann et al., 2012). According to the Food and Agricultural Organization, there are about 840 million undernourished people in 1998-2000, of whom 799 million are in developing countries, 30 million in the countries in transition and 11 million in the industrialized countries (Sartaj, 2001; Diouf, 2002; Gilani et al., 2010; Hussaini et al., 2010). To apprehend the situation, interests have been centralized on the exploitation, quantification and utilization of food plants (Dini et al., 2005). Coarse grains (cereal and legumes grains) being rich source of carbohydrates, protein and fat, which form the major part of human diets, are the most widely staple food used. At present, coarse grains have attracted more attention to common diet because they contain beneficial components. Among these products, millet, maize, sorghum, wheat, cowpea and rice are the most popular agricultural products consumed for medical purpose and maintaining good health (Huang et al., 2008).

In many developing countries, the supply of minerals is inadequate to meet the mineral requirements of farm animal and growing population. Minerals cannot be synthesized by animals and must be provided from plants and mineral-rich water (Mosha et al., 1995; Anjorin et al., 2010). Mineral composition of a plant plays a significant role in its nutritional, medicinal and therapeutic values (Alkharusi et al., 2009)

The amount of a mineral element in an animal tissue reflects the amount present in the food consumed by the animal, which is in turn a function of the element present in the soil, and the extent to which the plant concentrates it during growth (Mertz, 1980). Mineral elements serve one or more functions in the body. They are the constituents of skin, carrier proteins, protein hormones, as cofactors of enzymes and electrolytes in body fluids and cells (Okoye, 1992). Because of the rapid rate of growth and development in human, mineral element nutrition has become very essential. For instance, calcification of bone is needed in early infancy to support the weight of the body by the time the baby walks. Deficiencies or disturbances in the nutrition of an animal cause a variety of diseases and can arise in several ways (Gordon, 1977). When a trace element is deficient, a characteristic syndrome is produced which reflects the specific functions of the nutrient in the metabolism of the animal. However, all mineral elements can have adverse effect upon human and animals at excessively high concentration if included in the diet (Okoye et al., 2011). Mineral toxicity may also refer to toxic conditions resulting from certain diseases or injuries. For example, a disorder known as hemochromatosis leads to iron toxicity, while Wilson's disease results in copper toxicity. Severe trauma can lead to hyperkalemia or potassium toxicity. Iron accumulation has been related to some neurologic disorders such as Alzheimer disease, Parkinson disease, type-1 neuro-degeneration with brain iron accumulation and other disorders (Sadrzadeh and Saffari, 2004). The objective of this work is to determine the concentration levels of $\mathrm{Na}$, $\mathrm{Mg}, \mathrm{K}, \mathrm{Ca}, \mathrm{Mn}, \mathrm{Fe}, \mathrm{Cu}$ and $\mathrm{Zn}$ in some selected coarse grains consumed by the inhabitants of Kano, Nigeria. Also, compares the levels of these metals in the grains analyzed to that of international standard for food consumption. This information may serve as a guide to the nutritional value and pollution potential of some coarse grains due to their mineral contents. 


\section{MATERIALS AND METHODS}

All glass and plastic wares containers were washed with detergent and rinsed with distilled water, then soaked overnight in $6 \mathrm{M} \mathrm{HNO}_{3}$ solution and rinsed several times with deionized water to eliminate absorbance due to detergent (Cabrera, 1994). Analar grade reagents and deionized water were used throughout the analysis. Buck Scientific Model Atomic Absorption Spectrophotometer(AAS Model 210VGP) was used for the analysis of magnesium, calcium, manganese, Iron, copper and zinc. While Jenway Clinical Model PFC-7 Flame Photometer was used for the analysis of sodium and potassium.

\section{Sampling}

Three varieties each of cowpea, maize, millet, rice, sorghum and wheat were obtained from the Dawanau Grains Market, Kano and Agronomy Department of Bayero University, Kano. The varieties are; Cowpea Dan misra, Cowpea ITA 499 and Cowpea ITA 573 for Cowpea, Maize QPM, Maize EVDT and Yellow Maize for Maize, Millet Zango,Millet Wuayan Bijimi and Late Millet (maiwa) for Millet, Rice SIPI, Rice TOX and Rice Yar Mahangi for Rice, Sorghum Kaura, Sorghum ICSV and Sorghum ML4 for Sorghum and Wheat Pavon, Wheat Attila and Sitte-ceros for Wheat.

\section{Sample Preparation}

The grains were washed with deionised water and ovum dried at $65^{\circ} \mathrm{C}$ for 6 hours. The dried samples were ground to fine powder using stainless steel motor and pestil. $1 \mathrm{~g}$ of each of the powdered components was digested as reported by Howe et al., (2005).

\section{Wet Digestion Method}

To $1.0 \mathrm{~g}$ of powdered sample in $100 \mathrm{~cm}^{3}$ beaker, $20 \mathrm{~cm}^{3}$ of $1: 3 \mathrm{HCl}: \mathrm{HNO}_{3}$ was added. The beaker was covered with a watch glass and was allowed to stand overnight. The following day the samples were digested at $110^{\circ} \mathrm{C}$ for $60 \mathrm{mins}$, using hot plate. The solution was allowed to cool and made up to the mark of $50 \mathrm{~cm}^{3}$ volumetric flask with $2 \% \mathrm{HNO}_{3}$. The flask was then covered and kept for analysis (Howe et al., 2005). The blank was prepared using the same procedure above but in this case the sample was excluded.

\section{Statistical Analysis}

Levels of mineral elements were subjected to one way analysis of variance (ANOVA) to access whether they varied significantly between the varieties of coarse grains. All statistical calculation were performed with Microsoft excel 2007.

\section{RESULTS AND DISCUSSION}

\section{Sodium}

The sodium content of the coarse grains samples analyzed ranged from $62.50 \pm 0.55$ to $84.82 \pm 0.74 \mathrm{mg} / \mathrm{kg}$ (Table 1). Significant difference $(p<0.05)$ occurred in Sodium concentration across the varieties of coarse grains samples analyzed. The mean concentration of sodium in the three varieties of the coarse grains analyzed was $82.25 \mathrm{mg} / \mathrm{kg}$ for cowpea, $69.92 \mathrm{mg} / \mathrm{kg}$ for maize, $76.19 \mathrm{mg} / \mathrm{kg}$ for millet, $75.03 \mathrm{mg} / \mathrm{kg}$ for rice, $82.74 \mathrm{mg} / \mathrm{kg}$ for sorghum and $81.85 \mathrm{mg} / \mathrm{kg}$ for wheat. The highest concentration of sodium was found in cowpea ITA 499 and sorghum ML4 with concentration of $84.82 \pm 0.45 \mathrm{mg} / \mathrm{kg}$ and $84.82 \pm 0.74 \mathrm{mg} / \mathrm{kg}$. The lowest concentration was found in maize QPM with concentration of $62.50 \pm 0.55 \mathrm{mg} / \mathrm{kg}$. Alayande et al., (2012), reported mean values of $84.65 \mathrm{mg} / \mathrm{kg}$ and $78.15 \mathrm{mg} / \mathrm{kg}$ sodium in white and brown cowpea, the values are within the range reported in this study for coarse grains. Sodium is essential to humans, used for regulating blood pressure and blood volume, and critical for muscle and nerve function. The recommended daily intake for sodium is $1200 \mathrm{mg} /$ day for children between the ages of $4-8$ years and $1500 \mathrm{mg} /$ day for adults between the ages of 18 - 50 years (FNB, 2013).

\section{Magnesium}

The magnesium content of the coarse grains ranged from $73.33 \pm 0.35$ to $317.00 \pm 0.10 \mathrm{mg} / \mathrm{kg}$ (Table 1 ). There was no significant difference $(p>0.05)$ in Magnesium concentration in varieties of coarse grains samples analyzed. The mean concentration of magnesium from the varieties of coarse grains samples analyzed was $281.67 \mathrm{mg} / \mathrm{kg}$ for cowpea, $228.22 \mathrm{mg} / \mathrm{kg}$ for maize, $302.44 \mathrm{mg} / \mathrm{kg}$ for millet, $305.67 \mathrm{mg} / \mathrm{kg}$ for rice, $191.56 \mathrm{mg} / \mathrm{kg}$ for sorghum and $195.78 \mathrm{mg} / \mathrm{kg}$ for wheat. The highest concentration of magnesium was found in millet maiwa with concentration of $317.00 \pm 0.10 \mathrm{mg} / \mathrm{kg}$. The lowest concentration was found in maize QPM with concentration of $73.33 \pm 0.35 \mathrm{mg} / \mathrm{kg}$. Johann et al., (2012), reported mean value of $1205 \mathrm{mg} / \mathrm{kg}$ and $371 \mathrm{mg} / \mathrm{kg}$ magnesium in brown and white rice. The value for white rice is in accordance with the result obtained in this study and that of brown rice is relatively higher than the result obtained for all the grains analyzed. Symptoms of magnesium deficiency ranges from growth retardation, nausea, muscle weakness and this deficiency may affect cardiac functions (McDowell, 1992). The recommended daily intake for magnesium in male adult is $420 \mathrm{mg} /$ day and that of female adult is $320 \mathrm{mg} /$ day $(\mathrm{NIH}, 2013)$.

\section{Potassium}

Significant difference $(p<0.05)$ occurred in Potassium concentration across the varieties of coarse grains samples analyzed. The Potassium content of the coarse grains ranged from $89.22 \pm 0.26$ to $193.33 \pm 0.33 \mathrm{mg} / \mathrm{kg}$ (Table 1). The mean concentration of magnesium from the varieties analyzed was $189.34 \mathrm{mg} / \mathrm{kg}$ for cowpea, $135.61 \mathrm{mg} / \mathrm{kg}$ for maize, $135.29 \mathrm{mg} / \mathrm{kg}$ for millet, $114.38 \mathrm{mg} / \mathrm{kg}$ for rice, $146.72 \mathrm{mg} / \mathrm{kg}$ for sorghum and $128.17 \mathrm{mg} / \mathrm{kg}$ for wheat. The highest concentration of potassium was found in cowpea Dan misra with concentration of $193.33 \pm 0.33 \mathrm{mg} / \mathrm{kg}$. The lowest concentration was found in yellow maize with concentration of $89.22 \pm 0.26 \mathrm{mg} / \mathrm{kg}$. Alayande et al., (2012), reported mean values of $768.05 \mathrm{mg} / \mathrm{kg}$ and $741.29 \mathrm{mg} / \mathrm{kg}$ potassium in white and brown cowpea, the values are much higher than the range reported in this study for coarse grains. Potassium is the third most abundant mineral in the human body and is essential to human life. The Recommended Dietary Allowance for potassium in adults between the ages of 15 to above is $3500 \mathrm{mg} /$ day (COMA, 1991). 


\section{Calcium}

The calcium content of the coarse grains ranged from $63.33 \pm 0.32$ to $186.67 \pm 0.27 \mathrm{mg} / \mathrm{kg}$ (Table 1 ). Significant difference $(p<0.05)$ occurred in Potassium concentration across the varieties of coarse grains samples analyzed. The mean concentration of calcium from the varieties of coarse grains samples analyzed was $167.67 \mathrm{mg} / \mathrm{kg}$ for cowpea, $83.33 \mathrm{mg} / \mathrm{kg}$ for maize, $155.89 \mathrm{mg} / \mathrm{kg}$ for millet, $136.33 \mathrm{mg} / \mathrm{kg}$ for rice, $85.67 \mathrm{mg} / \mathrm{kg}$ for sorghum and $124.22 \mathrm{mg} / \mathrm{kg}$ for wheat. The highest concentration of calcium was found in cowpea ITA 573 with concentration of $186.67 \pm 0.27 \mathrm{mg} / \mathrm{kg}$. The lowest concentration was found in sorghum kaura with concentration of $63.33 \pm 0.32 \mathrm{mg} / \mathrm{kg}$. Johann et al., (2012), reported mean value of $104 \mathrm{mg} / \mathrm{kg}$ and $127 \mathrm{mg} / \mathrm{kg}$ calcium in brown and white rice. These mean values are in agreement with the ones reported in this study for coarse grains. Calcium is stored mostly in the bones and teeth. It is also essential for muscle contraction, nervous system function, blood vessel expansion and contraction, and secretion of hormones and enzymes (McDowell, 1992). Adequate intake of calcium for adults is $1000-1300 \mathrm{mg} /$ day, depending on age and gender (NIH, 2013).

Table 1: Concentration of $\mathrm{Na}, \mathrm{Mg}, \mathrm{K}$ and $\mathrm{Ca}$ in the varieties of coarse grains $(\mathrm{mg} / \mathrm{kg}$ )

\begin{tabular}{lcccc}
\hline Coarse Grains & $\mathbf{N a}$ & $\mathbf{M g}$ & $\mathbf{K}$ & $\mathbf{C a}$ \\
\hline Cowpea & & & & \\
Dan Misra & $80.36 \pm 0.35$ & $300.67 \pm 0.41$ & $193.33 \pm 0.19$ & $180.00 \pm 0.43$ \\
ITA 499 & $83.04 \pm 0.17$ & $304.00 \pm 1.00$ & $186.27 \pm 0.04$ & $136.33 \pm 0.35$ \\
ITA 573 & $80.36 \pm 0.60$ & $240.33 \pm 0.31$ & $188.43 \pm 0.33$ & $186.67 \pm 0.29$ \\
Maize & & & & \\
QPM & $62.50 \pm 0.55$ & $73.33 \pm 0.35$ & $158.80 \pm 010$ & $70.00 \pm 0.52$ \\
EVDT & $66.00 \pm 0.41$ & $310.67 \pm 1.41$ & $158.80 \pm 0.25$ & $80.00 \pm 1.50$ \\
Yellow Maize & $81.25 \pm 0.12$ & $300.67 \pm 0.66$ & $89.22 \pm 0.26$ & $100.00 \pm 2.65$ \\
Millet & & & & \\
Zango & $75.89 \pm 0.19$ & $277.00 \pm 0.70$ & $157.84 \pm 0.24$ & $160.00 \pm 0.51$ \\
Wuyan Bijimi & $76.79 \pm 0.20$ & $313.33 \pm 0.27$ & $158.80 \pm 0.79$ & $137.00 \pm 0.87$ \\
Lare Millet & $75.89 \pm 0.57$ & $317.00 \pm 0.10$ & $137.45 \pm 0.06$ & $170.67 \pm 0.58$ \\
Rice & & & & \\
SIPI & $72.32 \pm 0.15$ & $306.67 \pm 0.10$ & $102.94 \pm 0.16$ & $94.33 \pm 0.30$ \\
TOX & $76.89 \pm 0.25$ & $300.33 \pm 0.09$ & $102.94 \pm 0.45$ & $163.33 \pm 0.35$ \\
Yar Mahangi & $75.89 \pm 0.81$ & $310.00 \pm 0.05$ & $137.25 \pm 0.05$ & $151.33 \pm 0.60$ \\
Sorghum & & & & \\
Kaura & $82.14 \pm 0.12$ & $273.67 \pm 0.49$ & $158.80 \pm 0.19$ & $63.33 \pm 0.32$ \\
ICVS & $81.25 \pm 0.30$ & $100.67 \pm 0.49$ & $130.39 \pm 0.77$ & $86.67 \pm 0.062$ \\
ML4 & $84.82 \pm 0.74$ & $200.33 \pm 0.29$ & $150.98 \pm 0.18$ & $107.00 \pm 0.87$ \\
Wheat & & & & \\
Pavon & $82.14 \pm 0.006$ & $140.00 \pm 0.50$ & $123.53 \pm 0.25$ & $157.33 \pm 0.39$ \\
Attila & $83.04 \pm 0.17$ & $200.00 \pm 0.25$ & $109.80 \pm 0.20$ & $136.00 \pm 1.00$ \\
Sitte-ceros & $80.36 \pm 0.60$ & $247.33 \pm 0.29$ & $151.18 \pm 0.33$ & $79.33 \pm 0.24$ \\
\hline Values are the & & &
\end{tabular}

Values are the average of three replicates on each treatment \pm SD.

\section{Manganese}

There was no significant difference $(p>0.05)$ in Manganese concentration in varieties of coarse grains samples analyzed. The manganese content of the coarse grains samples analyzed ranged from $1.00 \pm 0.11$ to $20.50 \pm 1.30 \mathrm{mg} / \mathrm{kg}$ (Table 2 ). The mean concentration of manganese from the varieties analyzed was $6.33 \mathrm{mg} / \mathrm{kg}$ for cowpea, $3.50 \mathrm{mg} / \mathrm{kg}$ for maize, $5.33 \mathrm{mg} / \mathrm{kg}$ for millet, $9.60 \mathrm{mg} / \mathrm{kg}$ for rice, $7.33 \mathrm{mg} / \mathrm{kg}$ for sorghum and $13.00 \mathrm{mg} / \mathrm{kg}$ for wheat. The highest concentration of calcium was found in wheat pavon with concentration of $20.5 \pm 1.30 \mathrm{mg} / \mathrm{kg}$. The lowest concentration was found in maize QPM with concentration of $1.00 \pm 0.11 \mathrm{mg} / \mathrm{kg}$. Johann et al., (2009), reported manganese content of 5.02 to $17.10 \mathrm{mg} / \mathrm{kg}$ and 5.19 to $43.50 \mathrm{mg} / \mathrm{kg}$ with mean of $10.50 \mathrm{mg} / \mathrm{kg}$ and $26.50 \mathrm{mg} / \mathrm{kg}$ in white and brown rice. These values are within the range reported in this study for coarse grains. Manganese is essential to human beings. It can function as an enzyme activator for several enzymes and as a component of some metalloenzymes (Crossgrove and Zheng, 2004). Although there is no established recommended daily allowance for manganese it is estimated that adult males and females require 2.3 and $1.8 \mathrm{mg}$ per day respectively. An upper limit of $11 \mathrm{mg}$ per day for adults has been determined (NIH, 2013).

\section{Iron}

The iron content of the coarse grains ranged from $25.00 \pm 0.11$ to $90.00 \pm 0.71 \mathrm{mg} / \mathrm{kg}$ (Table 2). There was no significant difference $(p>0.05)$ in Iron concentration in varieties of coarse grains samples analyzed. The mean concentration of iron from the varieties analyzed was $48.5 \mathrm{mg} / \mathrm{kg}$ for cowpea, $50.17 \mathrm{mg} / \mathrm{kg}$ for maize, $48.5 \mathrm{mg} / \mathrm{kg}$ for millet, $50.67 \mathrm{mg} / \mathrm{kg}$ for rice, $58.33 \mathrm{mg} / \mathrm{kg}$ for sorghum and $66.67 \mathrm{mg} / \mathrm{kg}$ for wheat. The highest concentration of iron was found in wheat pavon with concentration of $90.00 \pm 0.71 \mathrm{mg} / \mathrm{kg}$. 
The lowest concentration was found in rice yar mahangi with concentration of $25.00 \pm 0.11 \mathrm{mg} / \mathrm{kg}$. Johann et al., (2009), reported iron content of 3.10 to $153.00 \mathrm{mg} / \mathrm{kg}$ and 12.80 to $38.20 \mathrm{mg} / \mathrm{kg}$ with mean of $22.30 \mathrm{mg} / \mathrm{kg}$ and $20.10 \mathrm{mg} / \mathrm{kg}$ in white and brown rice. These values are within the range reported in this study for coarse grains. Most of the iron in the body is found in heme proteins such as hemoglobin and myoglobin, both involved in oxygen transport. Iron is also found as a constituent of heme enzymes such as cytochromes, catalases and peroxidizes and other non heme compounds (McDowell, 1992). The Recommended Dietary Allowance for iron in adult female between the ages of 19 to $50 y e a r s$ is $8 \mathrm{mg} /$ day, those above 50 years is $18 \mathrm{mg} /$ day. In adult males, the RDA is $8 \mathrm{mg} /$ day ( $\mathrm{NIH}, 2013)$.

\section{Copper}

The copper content of the varieties of coarse grains ranged from $4.00 \pm 0.08$ to $13.00 \pm 0.24 \mathrm{mg} / \mathrm{kg}$ (Table $2)$. There was no significant difference $(p>0.05)$ in Copper concentration in varieties of coarse grains samples analyzed. The mean concentration of copper from the varieties analyzed was $5.00 \mathrm{mg} / \mathrm{kg}$ for cowpea, $8.33 \mathrm{mg} / \mathrm{kg}$ for maize, $9.33 \mathrm{mg} / \mathrm{kg}$ for millet, $6 \mathrm{mg} / \mathrm{kg}$ for rice, $9.33 \mathrm{mg} / \mathrm{kg}$ for sorghum and $6.33 \mathrm{mg} / \mathrm{kg}$ for wheat. The highest concentration of copper was found in sorghum ML4 with concentration of $13.00 \pm 0.24 \mathrm{mg} / \mathrm{kg}$. The lowest concentration was found in cowpea ITA499 and wheat attila with concentration of $4.00 \pm 0.08 \mathrm{mg} / \mathrm{kg}$ and $4.00 \pm 0.04 \mathrm{mg} / \mathrm{kg}$. Johann et al. (2012), reported brown and white rice to have range of 1.60 to $4.74 \mathrm{mg} / \mathrm{kg}$ and 0.78 to $2.71 \mathrm{mg} / \mathrm{kg}$ with mean of $2.96 \mathrm{mg} / \mathrm{kg}$ and $1.65 \mathrm{mg} / \mathrm{kg}$ of Copper. Also Chavan et al., (2009), reported range of 0.53 to $1.08 \mathrm{mg} / \mathrm{kg}$ with mean of $0.86 \mathrm{mg} / \mathrm{kg}$ copper in some varieties of sorghum. The copper content of coarse grains obtained in this study was higher than the above reports. Copper is essential to humans in small quantities, it is a key component of redox enzymes and hemocyanin. The Recommended Daily Allowance for copper in healthy adult is $3 \mathrm{mg} /$ day (NIH, 2013).

\section{Zinc}

Zinc content of the coarse grains ranged from $15.00 \pm 0.34$ to $50.50 \pm 0.24 \mathrm{mg} / \mathrm{kg}$ (Table 2). There was no significant difference $(p>0.05)$ in Zinc concentration in varieties of coarse grains samples analyzed. The The mean concentration of zinc from the varieties of coarse grains samples analyzed was $32.66 \mathrm{mg} / \mathrm{kg}$ for cowpea, $30.50 \mathrm{mg} / \mathrm{kg}$ for maize, $27.50 \mathrm{mg} / \mathrm{kg}$ for millet, $32.00 \mathrm{mg} / \mathrm{kg}$ for rice, $23.83 \mathrm{mg} / \mathrm{kg}$ for sorghum and $32.83 \mathrm{mg} / \mathrm{kg}$ for wheat. The highest concentration of copper was found in rice TOX and cowpea ITA 573 with concentration of $50.50 \pm 0.24 \mathrm{mg} / \mathrm{kg}$ and $50.50 \pm 0.24 \mathrm{mg} / \mathrm{kg}$. The lowest concentration was found in wheat sitte-ceros with concentration of $15.00 \pm 0.34 \mathrm{mg} / \mathrm{kg}$. Abu et al. (2000), reported zinc content with range values of 0.39 to $25.61 \mathrm{mg} / \mathrm{kg}$ in sorghum, which are lower than those reported in this study. Zinc is very important for nerve function and male fertility. It is very important for normal sexual development especially for the development of testes and ovaries, it is also essential for reproduction (Ayoola et al., 2010). The Recommended Dietary Allowance for zinc in children between the ages of 1 to 3 years is $3 \mathrm{mg} /$ day, those between the ages of 9 to $13 y$ ears is $8 \mathrm{mg} /$ day. The RDA for zinc in male adult is $11 \mathrm{mg} /$ day and for female adult is $8 \mathrm{mg} /$ day $(\mathrm{NIH}, 2013)$.

Table 2: Concentration of $\mathrm{Mn}, \mathrm{Fe}, \mathrm{Cu}$ and $\mathrm{Zn}$ in the varieties of coarse grains $(\mathrm{mg} / \mathrm{kg})$

\begin{tabular}{lcccc}
\hline Coarse Grains & $\mathbf{M n}$ & $\mathbf{F e}$ & $\mathbf{C u}$ & $\mathbf{Z n}$ \\
\hline Cowpea & & & & \\
Dan Misra & $6.00 \pm 0.27$ & $40.50 \pm 0.50$ & $5.00 \pm 0.17$ & $22.00 \pm 0.50$ \\
ITA 499 & $4.00 \pm 0.11$ & $55.00 \pm 0.61$ & $4.00 \pm 0.08$ & $25.50 \pm 0.47$ \\
ITA 573 & $9.00 \pm 0.20$ & $50.00 \pm 0.77$ & $6.00 \pm 0.10$ & $50.50 \pm 0.24$ \\
Maize & & & & \\
QPM & $1.00 \pm 0.11$ & $40.5 \pm 0.33$ & $5.00 \pm 0.32$ & $40.00 \pm 1.00$ \\
EVDT & $2.00 \pm 0.12$ & $35.00 \pm 0.21$ & $8.00 \pm 0.10$ & $20.50 \pm 0.71$ \\
Yellow Maize & $7.50 \pm 0.18$ & $75.00 \pm 0.12$ & $12.00 \pm 0.09$ & $31.00 \pm 0.66$ \\
Millet & & & & \\
Zango & $3.50 \pm 0.28$ & $60.00 \pm 0.78$ & $10.00 \pm 0.24$ & $15.50 \pm 0.43$ \\
Wuyan Bijimi & $5.50 \pm 0.51$ & $50.50 \pm 0.37$ & $8.00 \pm 0.16$ & $30.00 \pm 0.13$ \\
Lare Millet & $7.00 \pm 0.08$ & $35.00 \pm 0.31$ & $10.00 \pm 0.07$ & $37.00 \pm 0.54$ \\
Rice & & & & \\
SIPI & $5.00 \pm 0.13$ & $25.00 \pm 0.11$ & $6.00 \pm 0.17$ & $25.00 \pm 0.25$ \\
TOX & $12.5 \pm 0.34$ & $80.50 \pm 0.36$ & $7.00 \pm 0.19$ & $20.50 \pm 0.40$ \\
Yar Mahangi & $16.50 \pm 0.50$ & $46.50 \pm 0.26$ & $5.00 \pm 0.26$ & $50.50 \pm 0.41$ \\
Sorghum & & & & \\
Kaura & $6.00 \pm 0.53$ & $60.00 \pm 0.64$ & $5.00 \pm 0.11$ & $25.00 \pm 0.70$ \\
ICVS & $13.00 \pm 0.24$ & $55.00 \pm 0.84$ & $10.00 \pm 0.26$ & $15.00 \pm 0.34$ \\
ML4 & $3.00 \pm 0.08$ & $60.00 \pm 0.77$ & $13.00 \pm 0.24$ & $31.50 \pm 0.52$ \\
Wheat & & & & \\
Pavon & $20.50 \pm 1.30$ & $90.00 \pm 0.71$ & $7.00 \pm 0.15$ & $41.00 \pm 0.92$ \\
Attila & $11.50 \pm 0.20$ & $45.00 \pm 0.58$ & $4.00 \pm 0.22$ & $21.00 \pm 0.26$ \\
Sitte-ceros & $7.00 \pm 0.61$ & $65.00 \pm 0.13$ & $8.00 \pm 0.42$ & $36.50 \pm 0.52$ \\
\hline Values are & & &
\end{tabular}

Values are the average of three replicates on each treatment \pm SD. 


\section{CONCLUSION}

While the six coarse grains analyzed are considered the major staple food consumed by the Kano metroplis inhabitant, the result of the study shows that concentration of potassium, calcium and zinc was generally higher in cowpea, that of sodium was higher in sorghum. The level of magnesium and manganese was relatively higher in rice, that of iron was higher in wheat and Millet has the highest concentration of

\section{REFERENCES}

Abu, A.E., Aba, D.A., Chindo, P.S., Ango, K.M. and Maigida, D.N. (2000). Evaluation of sorghum grain for traditional and industrial uses. Institute of agricultural research, Zaria.

Anjorin, T. S., Ikokoh, P. and Okolona, S. (2010). Mineral Composition of Moringa oleifera Leaves, Pods and Seeds from two region in Abuja, Nigeria. International Journal of Agriculture and. Biology, 12: $431-434$

Al-kharusi, L. M., Elmardi M. O., Ali, A., Al-Said, F. A. J., Abdelbasit K. M. and Al-Rawahi, S. (2009). Effect of Mineral and Organic Fertilizers on the Chemical Characters and Quality of Date Fruits. International Journal of Agriculture and. Biology, 11: 290- 296

Alayande, L. B., Mustapha, K. B., Dabak, J. D. and Ubom, G. A. (2012). Comparison of Nutritional Values of Brown and White Beans in Jos North Local Government Markets. African Journal of Biotecnology, Vol. 11(43), pp. 10135-10140

Anyoola, P. B., Adeyeye, A., and Onawumi O. O., (2010). Trace Elements and Major Evaluation of Spondias mombin, Veronica anygdadina and Momordica charantia Leaves. Pakistan Journal of Nutrition, 9(1): 91- 92

Cabrera, C., Gallego, C., Lopez, M. C. and Lorenzo, M. L. (1994). Determination of levels of lead contamination in food and feed crops. JAOAC Int 77: 249-252

Chavan, U. D, Patil, J. V. and Shinde, M. S. (2009). Nutritional and Roti quality of Sorghum Genotypes, Indonesian Journal of Agricultural Science 10 (2): 80-87

COMA (Committee on Medical Aspects of Food Policy). (1991). Dietary Reference Values for Food Energy and Nutrients for the United Kingdom, No. 41. Department of Health. HMSO, London.

Crossgrove J. and Zheng W. (2004). Manganese toxicity upon overexposure. NMR in Biomedicine 17, 544-553.

Dini L, Tenore G C, and Dini A. (2005). Nutritional and AntiNutritional Composition of Kancolla Seeds: an interesting and underexploited andine food plant. Food Chemistry, 92: 125- 132

Diouf, J. (2002). The State of Food Insecurity in the World. Published by the Food and Agriculture Organization of the United Nations Viale delle Terme di Caracalla, 00100 Rome, Italy. pp 5153

FNB (Food and Nutrition Board), Institute of Medicine (2013), Dietary Reference Intakes (DRIs): Recommended Intakes for Individuals, Vitamins. National Academies, Accessible at http://www.iom.edu/Global/News\%20Announce copper. Comparing the result with Recommended Daily Allowances of essential and trace metals set by international standard organizations, the coarse grains contribute little to the provision of essential and trace element to meet the requirement of the Recommended Dietary Allowance. However, it is recommended to repeat the analysis using dry ashing method, to ascertain complete digestion of organic matter and also to compare the results.

ments/ /media/Files/Activity\%20Files/Nutrition/ DRIs/DRI Summary Listing.pdf

Gilani, S.A., Fujii, Y., Shinwari, Z.K., Adnan, M., Kikuchi, A. and Watanabe, KN. (2010). Phytotoxic studies of medicinal plant species of Pakistan. Pak. Journal of Botony., 42(2): 987 - 996.

Gordon, R. F. (1977). Poultry Diseases. The English Language Book Society and Bailliere Tindall, London.

Howe, A., Hoo Fung, L., Lalor, G., Rattray, R., Vutchkov, M., 2005. Elemental composition of Jamaican foods. 1: A survey of five food crop categories. Environmental Geochemistry and Health 27, 1930.

Huang Z., Li X.L., Wang J.S., Tu X.D. and Liu W. (2007) 'Vertical variations of particle number concentration and size distribution in a street canyon in Shanghai, China'. Science of the Total Environment 378:306-316.

Hussain J.,Rehman N., Khan A., Hamayun M, Hussain Z K S. (2010). Proximate and Essential Nutrients Evaluation of Selected Vegetables Species from Kohat Region, Pakistan. Pakistan Journal of Botany, 42(4):2847-2855

Johann M. R. A., Lesile A. H., Charles N. G., Haile T. D. and Gerald C. L. (2012). Dietary intake of minerals and trace elements in rice on the Jamaican Market. Journal of Food Composition and Analysis. 26: 111- 121

McDowell L. R. (1992). Minerals in Animal and Human Nutrition. Academic Press Inc., CA, USA.

Mertz, W. (1980). The Essential Trace Elements. Science. 213:1332.

Mosha T. C, Pace R. D., Adeyeye S., Mtcbe K., Laswai I.I. (1995). Proximate composition and mineral content of selected Tanzanian vegetables and the effect of traditional processing on the retention of ascorbic acid, riboflavin and thiamine. Plant Foods and Human Nutrition. 48: 235-245.

NIH (National Institute of Health), (2013). Health Professional Fact Sheet. Office of Dietary Supplements. Available at http://www.ods.od.nih.gov/factsheets

Okoye C. O. B., Ibeto C. N. and Ihedioha J. N. (2011). Assessment of heavy metals in chicken feeds sold in south eastern, Nigeria. Advances in Applied Science Research, 2 (3):63-68

Okoye Z.S.C (1992) Biochemical Aspects of Nutrition Prentice-Hall of India, New Delhi pp 147-195

Sartaj, A. (2001). Why 800 million people still hungry? Sustainable food security for all by 2020 . Bonn Germany, p. 82.

Sadrzadeh, S. M. and Saffari, Y. (2004). Iron and brain disorders. American Journal of Clinical Pathology, pp. 64-70. 